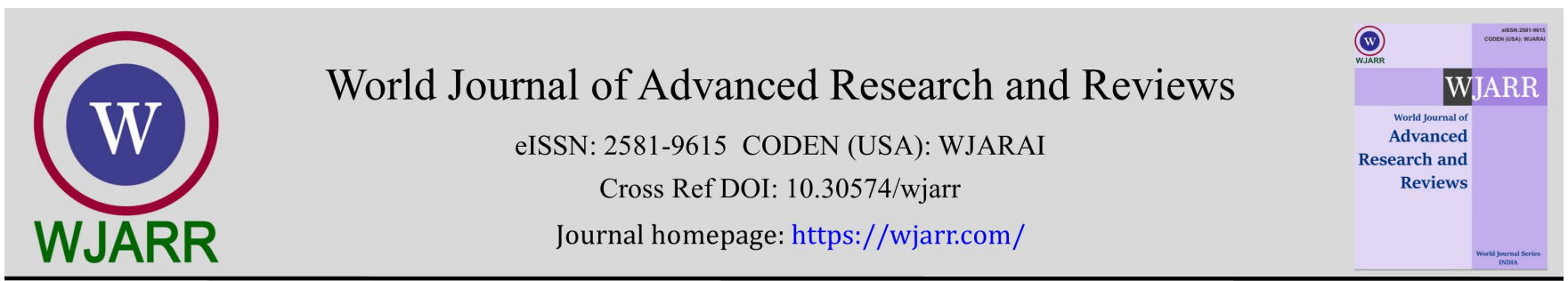

(RESEARCH ARTiClE)

\title{
Particle size and physical characteristic of corn milling results using hammer mill as poultry feed ingredients
}

\author{
Mustakin, Sri Purwanti and Jasmal A Syamsu* \\ Faculty of Animal Science, Universitas Hasanuddin, Makassar, Indonesia 90245.
}

World Journal of Advanced Research and Reviews, 2021, 11(02), 298-302

Publication history: Received on 21 July 2021; revised on 24 August 2021; accepted on 26 August 2021

Article DOI: https://doi.org/10.30574/wjarr.2021.11.2.0401

\begin{abstract}
Feed ingredients used in poultry feed, generally require size reduction before being used in mixing rations, such as corn. The process of reducing the size of corn is the initial process that must be carried out for ration production. The machine that is commonly used to reduce the size is the hammer mill. This study aims to determine the particle size and physical characteristics of corn as a poultry feed ingredient by grinding using a hammer mill. The study was arranged using a completely randomized design with four treatments of amount of corn milled with three replications. The treatments were P1 = $5 \mathrm{~kg}, \mathrm{P} 2=10 \mathrm{~kg}, \mathrm{P} 3=15 \mathrm{~kg}$, and P4 = $20 \mathrm{~kg}$. Parameters observed were particle size and degree of fineness of milled results, bulk density, and specific gravity, angle of repose, capacity and efficiency of hammer mill machine performance. The results showed that the largest particle size was P4 at $3.167 \mathrm{~mm}$ with a fineness degree of 4.927 and the smallest particle size was P1 at $2.810 \mathrm{~mm}$ with a fineness degree of 4.756. Overall, the category of corn milling results using a hammer mill is the category of coarse milling results. The results of the analysis of variance showed that the amount of corn milled treatment had no significant effect on the angle of repose, specific gravity and bulk density of corn milled using a hammer mill. The difference in the number of milled corn does not affect the difference in the particle size of the corn produced from the milling results, so it does not affect the angle of repose, specific gravity and bulk density.
\end{abstract}

Keywords: Corn; Feed; Hammer mill; Particle size; Physical characteristics

\section{Introduction}

Poultry farming is mostly 60-70 percent of the cost of production is the cost of feed. Therefore, poultry farmers or feed producers are being challenged to find cost-effective ration nutrition and feed processing strategies to remain profitable [1]. Most of the ingredients used in poultry feed require size reduction before being used as feed ingredients, for example, corn.

Reducing the particle size of corn is the first step in the feed production process. The feed milling process is one of the most important activities and requires about 70\% energy (power) compared to other processes in feed mills [2]. The general method that is widely used to reduce the particle size of the grain or feed material to a finer size is to use a roller mill and hammer mill.

Generally, hammer mills are used more often because of lower maintenance costs and simpler operations [3],[4], and are corn milling technology that works on the principle of impact [5]. Milling of feed ingredients using a hammer mill, one way to change the particle size by changing the size of the sieve (screen) with a smaller or larger hole diameter [6].

\footnotetext{
* Corresponding author: Jasmal A Syamsu

Faculty of Animal Science, Universitas Hasanuddin, Makassar, Indonesia 90245.

Copyright (C) 2021 Author(s) retain the copyright of this article. This article is published under the terms of the Creative Commons Attribution Liscense 4.0.
} 
Particle size is an important study material in relation to the digestive process and nutrient absorption by livestock, where in the digestive process there is a change in the ration particle size and solubility both mechanically and chemically [7]. Reducing the size or grinding of corn causes the surface area of the material to increase so that there is more interaction between digesta and digestive enzymes, as well as mixing uniformity (mixing), and reducing the separation of materials after mixing [8]. This study aims to determine the particle size and physical characteristics of corn as a feed ingredient by grinding using a hammer mill.

\section{Material and methods}

The research was conducted at the Feed Technology and Industry Laboratory, Faculty of Animal Science, Universitas Hasanuddin, Makassar, Indonesia. The study was arranged using a completely randomized design with four treatments of amount of corn milled with three replications. The treatments were P1 = $5 \mathrm{~kg}, \mathrm{P} 2=10 \mathrm{~kg}, \mathrm{P} 3=15 \mathrm{~kg}$, and P4 = $20 \mathrm{~kg}$. Corn was ground using a hammer mill with engine type specifications RD 85 DI-2S, capacity of $200 \mathrm{~kg} / \mathrm{hour}$, diesel motor 7.5/2200 HP/rpm, dimensions $46 \mathrm{~cm} \times 32 \mathrm{~cm} \times 31 \mathrm{~cm}$, number of beaters 60 hammers, and $5 \mathrm{~mm}$ sieve size (Figure 1).

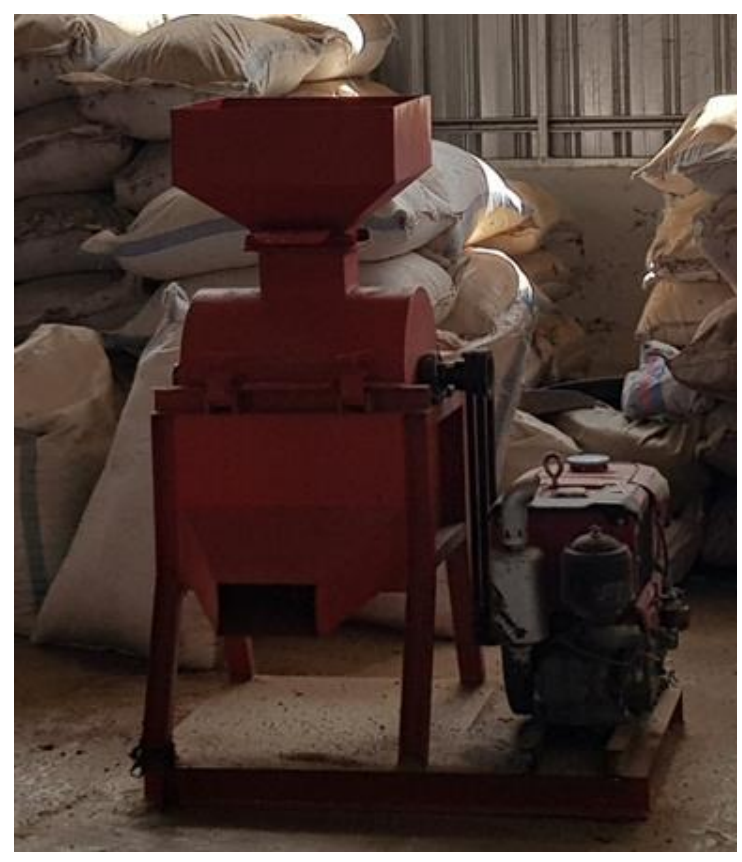

Figure 1 Hammer mill machine used in research

The corn used was obtained from Takalar Regency as much as $150 \mathrm{~kg}$ which was divided into 4 (four) parts for each treatment, namely P1 = $15 \mathrm{~kg}, \mathrm{P} 2=30 \mathrm{~kg}, \mathrm{P} 3=45 \mathrm{~kg}$, and P4 = $60 \mathrm{~kg}$. The corn milling process with the corn procedure is put into the hopper of the hammer mill machine according to each treatment. Then the hammer mill machine is turned on and the milling time is recorded until the corn in the hopper is completely ground. The milled results were accommodated in a storage container (sack) and the weight of the milled corn was weighed and samples were taken for analysis of the research parameters.

Parameters observed in this study were particle size and degree of fineness of the milled results [9],[10], bulk density and specific gravity [11], angle of repose [12], and capacity and efficiency hammer mill machine performance [13]. The data obtained were analyzed using variance using Microsoft Excel Data Analysis [14].

\section{Results and discussion}

The degree of fineness and the average particle size of corn milled using a hammer mill are as shown in Table 1 . The average degree of fineness is 4.834 with an average particle size of $2.973 \mathrm{~mm}$. The largest particle size is P4 of 3.167 $\mathrm{mm}$ with a degree of fineness of 4.927 and the smallest particle size is P1 of $2.810 \mathrm{~mm}$ with a degree of fineness of 4.756 . Overall, the category of corn milling results using a hammer mill is the category of coarse milling results. 
The results of the mill in the coarse category use less energy or power in the grinding process than the results of the fine mill [15]. The finer particle size can decrease intestinal peristalsis and increase feed consumption and transfer rate, thereby reducing feed digestibility [16]. Coarse feed structure has been shown to positively affect nutrient digestibility and livestock performance [17].

Table 1 Degree of fineness and particle size of corn milling results using hammer mill

\begin{tabular}{|c|c|c|l|}
\hline Treatment & Degree of Fineness (Modulus of Finenes) & Particle Size (mm) & Milling Results Category \\
\hline P1 & 4.756 & 2.810 & coarse particle size \\
\hline P2 & 4.811 & 2.924 & coarse particle size \\
\hline P3 & 4.843 & 2.990 & coarse particle size \\
\hline P4 & 4.927 & 3.167 & coarse particle size \\
\hline
\end{tabular}

Table 2 Average of angle of repose, specific gravity and bulk density of of corn milling results using hammer mill

\begin{tabular}{|c|c|c|c|}
\hline \multirow{2}{*}{ Treatment } & \multicolumn{3}{|c|}{ Parameters } \\
\cline { 2 - 4 } & Angle of repose ( ${ }^{\circ}$ ) & Specific Gravity $\mathbf{( k g} / \mathbf{m}^{\mathbf{3}}$ ) & Bulk Density $\mathbf{( k g} / \mathbf{m}^{\mathbf{3}}$ ) \\
\hline P1 & 29.8 & 1382.3 & 672.3 \\
\hline P2 & 26.9 & 1646.0 & 642.7 \\
\hline P3 & 28.8 & 1494.7 & 671.3 \\
\hline P4 & 30.2 & 1535.3 & 625.3 \\
\hline
\end{tabular}

Table 3 Theoretical and Actual Performance Capacity, Hammer Mill Machine Efficiency in Corn Milling

\begin{tabular}{|c|c|c|c|}
\hline Treatment & $\begin{array}{c}\text { Theoretical Performance } \\
\text { Capacity (kg/min) }\end{array}$ & $\begin{array}{c}\text { Actual Performance } \\
\text { Capacity (kg/min) }\end{array}$ & $\begin{array}{c}\text { Efficiency of The Hammer Mill } \\
\text { Machine (\%) }\end{array}$ \\
\hline P1.1 & 6.93 & 6.87 & 99.00 \\
\hline P1.2 & 8.54 & 8.46 & 99.00 \\
\hline P1.3 & 7.22 & 7.15 & 99.00 \\
\hline P2.1 & 10.00 & 9.95 & 99.50 \\
\hline P2.2 & 10.00 & 9.95 & 99.50 \\
\hline P2.3 & 10.91 & 10.85 & 99.50 \\
\hline P3.1 & 16.16 & 16.16 & 100.00 \\
\hline P3.2 & 15.99 & 15.99 & 100.00 \\
\hline P3.3 & 15.62 & 15.57 & 99.67 \\
\hline P4.1 & 19.91 & 19.86 & 99.75 \\
\hline P4.2 & 19.93 & 19.93 & 100.00 \\
\hline P4.3 & 19.94 & 19.94 & 100.00 \\
\hline Average & $13.43 \pm 5.04$ & $13.39 \pm 5.07$ & $99.58 \pm 0.40$ \\
\hline
\end{tabular}

The degree of fineness indicates the uniformity of the grinding results or the distribution of coarse and fine fractions [10]. The larger the mesh size and the longer the sieving time, the smaller the particle size obtained. Feed particle size 
is a critical point to measure feed digestibility and feed mix uniformity [18]. The difference in particle size in a milling process using a hammer mill is influenced by the type of grain used, the level of grain hardness, grain moisture content, screen size, motor speed and blade level used [1].

The average of angle of repose, specific gravity and bulk density of of corn milling results using hammer mill, can be seen in Table 2. The results of the analysis of variance showed that the amount of corn milled treatment had no significant effect on angle of repose, specific gravity, and bulk density of corn milling using a hammer mill. The difference in the number of milled corns did not affect the difference in the particle size of the corn produced from the milling results (Table 1), so it did not affect the angle of repose, specific gravity, bulk density.

The results of the calculation of the theoretical performance capacity, actual performance capacity and performance efficiency of the hammer mill machine in corn milling are as shown in Table 3. The average number of milled corn is $12.50 \mathrm{~kg}$ with an average corn milling time of 0.87 minutes and the weight of milled corn was $12.47 \mathrm{~kg}$.

The theoretical performance capacity of the hammer mill machine is $13.43 \mathrm{~kg} / \mathrm{minute}$ and the actual performance capacity is $13.39 \mathrm{~kg} /$ minute with a machine performance efficiency of $99.58 \%$. The performance efficiency of the hammer mill machine of $99.58 \%$ is included in the high efficiency category. Performance efficiency $80 \%$, meaning that the efficiency of using the machine is high, and if the efficiency of the machine's performance is below $80 \%$, it means that the efficiency of using the machine is low [19]. The efficiency of the hammer mill machine performance in the corn cob milling process is between $90-99 \%$ [20].

\section{Conclusion}

The treatment of the amount of corn milled did not significantly affect the angle of repose, bulk density, the specific gravity of corn milled using a hammer mill. Corn feed ingredients that are ground using a hammer mill are categorized as coarse milled.

\section{Compliance with ethical standards}

\section{Acknowledgments}

We thank the Laboratory of Feed Technology and Industry for providing hammer mill machines and other equipment for research.

\section{Disclosure of conflict of interest}

No conflict of interest.

\section{References}

[1] Pacheco W, Gulizia J, Vargas I. Effects of Diet Particle Size on Poultry Performance. Extension Poultry Science, Auburn University. ANR-2289. 2021.

[2] Dabbour MI, Bahnasawy A, Ali S, El- Haddad Z. Grinding Parameters and their Effects on the Quality of Corn for Feed Processing. J Food Process Technol. 2015; 6: 482.

[3] Patterson PH, Kitto LD. Corn milling efficiency and particle size effects on pullet growth performance and reproductive development. Proceeding of 6th Mediterranean Poultry Summit (MPS). Italy, June 2018; 18-20.

[4] Braun MB, Dunmire KM, Evans CE, Stark CR, Paulk CB. Effects of Grinding Corn with Different Moisture Concentrations on Subsequent Particle Size and Flowability Characteristics. Kansas Agricultural Experiment Station Research Reports. 2019; 5(8).

[5] Brennan JG, Butters JR, Cowell ND, Lilly AEV. Food Engineering Operations, 3rd ed. Elsevier Science Publishing Co., New York. 1990.

[6] Saensukjaroenphon M, Evans CE, Sheldon KH, Jones CK, Paulk CB, Stark CR. The Effect of Hammermill Screen Hole Diameter and Hammer Tip Speed on Particle Size and Flowability of Ground Corn. Kansas Agricultural Experiment Station Research Reports. 2017; 3(7).

[7] Blair R. Nutrition and Feeding of Organic Poultry. 2nd Edition. CAB International, UK. 2008. 
[8] Rubio AA, Hess JB, Berry WD, Dozier III WA, Pacheco WJ. Effects of corn particle size on broiler performance during the starter, grower, and finisher periods. Journal of Applied Poultry Research. 2020; 29(2): 352.

[9] ASAE. Method of Determining and Expressing Fineness of Feed Materials by Sieving. In ASAE, ASAE Standard S319.2. American Society of Agricultural and Biological Engineers: St. Joseph, MI. 1995.

[10] Henderson SM, Perry RL. Agricultural process engineering. The AVI Pub. Co. Inc., Wesport, Connecticut. 1976.

[11] Khalil. Pengaruh kandungan air dan ukuran partikel terhadap perubahan perilaku fisik bahan pakan lokal: kerapatan tumpukan, kerapatan pemadatan tumpukan, dan berat jenis. Media Peternakan. 1999; 22(1): 1-11.

[12] Khalil. Pengaruh kandungan air dan ukuran partikel terhadap perubahan perilaku fisik bahan pakan lokal: sudut tumpukan, daya ambang dan faktor higroskopis. Media Peternakan. 1999; 22(1): 33-42.

[13] Purwantoro D, T Dianpratiwi, S Markumningsih. Analisis Penggunaan Alat Mesin Pertanian Berbasis Traktor Tangan pada Kegiatan Perawatan Budidaya Tebu. Agritech. 2018; 38(3): 313-318.

[14] Berk KN, Caray P. Data Analysis with Microsoft@ Excel: Updated for Office 2007®. Third Edition. Brooks/Cole, Cengage Learning, Boston USA. 2010.

[15] Frank R, Pozza PC, Scherer C, Schöne RA, Avila AS, Oliveira PL, Broch J, Eyng C, Nunes RV. Effects of feed particle size on energy values for broiler chickens at various ages. South African Journal of Animal Science. 2020; 50(6): 830-839.

[16] Svihus B, Hetland H, Choct M, Sundby F. Passage rate through the anterior digestive tract of broilerchickens fed on diets with ground and whole wheat. Br. Poult. Sci. 2002; 43: 662-668.

[17] Xu Y, Stark CR, Ferket PR, Williams CM, Pacheco WJ, Brake J. Effect of dietary coarsely ground corn on broiler live performance, gastrointestinal tract development, apparent ileal digestibility of energy and nitrogen, and digesta particle size distribution and retention time. Poultry Sci. 2015; 94: 53-60.

[18] Baker S, Herrman T. Evaluating Particle Size. MF-2051. Kansas State University Agricultural Experiment Station and Cooperative Extension Service. 2002.

[19] Smith HP, Wilkes LH. Mesin dan Peralatan Usaha Tani. Terjemahan Tri Purwadi. UGM Press. Yogyakarta. 1990.

[20] Latief MF, Syamsu JA, Jamila Jamilah. Kinerja Teoritis, Kinerja Aktual dan Efesensi Mesin Hummer Mill pada Penggilingan Tongkol Jagung. Buletin Nutrisi dan Makanan Ternak. 2019; 13(2): 78-81. 